\title{
Detection and characterization of Bonamia ostreae in Ostrea edulis imported to China
}

\author{
Chunyan Feng ${ }^{1,2, *}$, Xiangmei Lin ${ }^{1, *}$, Fei Wang ${ }^{1}$, Yongning Zhang ${ }^{1}$, Jizhou Lv ${ }^{1}$, \\ Caixia Wang ${ }^{1}$, Junhua Deng ${ }^{1}$, Lin Mei ${ }^{1}$, Shaoqiang $\mathrm{Wu}^{1, * *}$, Huailin $\mathrm{Li}^{1{ }^{1 * * *}}$
}

${ }^{1}$ Institute of Animal Quarantine, Chinese Academy of Inspection and Quarantine, Beijing 100029, PR China

${ }^{2}$ Research Center for Eco-Environmental Sciences, Chinese Academy of Sciences, Beijing 100085, PR China

\begin{abstract}
The protozoan parasite Bonamia ostreae is a destructive pathogen of flat oysters and has been reported to be widespread in Europe and North America. The biological characteristics of this unicellular parasite are still not fully understood. In this study, 104 Ostrea edulis imported from the USA to the Guangdong province of China for consumption were examined for Bonamia infection. PCR assay, combined with restriction fragment length polymorphism, sequencing and BLAST analysis, showed that B. ostreae DNA could be detected in 1 of the 104 oyster samples. Light microscopy revealed Bonamia-like organisms in the oyster. PCR assay and fluorescent in situ hybridization showed that $B$. ostreae organisms were present and retained their integrity after $4 \mathrm{wk}$ in culture. Acridine orange-ethidium bromide staining indicated that the $B$. ostreae were still alive. In conclusion, $B$. ostreae was present in oysters imported to China. More importantly, the parasite was able to survive for at least $4 \mathrm{wk}$ of in vitro culture at $4^{\circ} \mathrm{C}$, which further implied a long-term transmission risk of $B$. ostreae. Considering the wide culture beds of Crassostrea ariakensis and C. gigas in China, and that $C$. ariakensis and C. gigas are susceptible hosts or reservoirs of $B$. ostreae, our study highlights the potential risk of introducing $B$. ostreae by importing $O$. edulis from a Bonamia endemic area.
\end{abstract}

KEY WORDS: Bonamia ostreae $\cdot$ Ostrea edulis $\cdot$ In vitro culture characterization $\cdot$ Fluorescent in situ hybridization $\cdot$ Transmission risk

\section{INTRODUCTION}

Bonamia ostreae is an intracellular protozoan parasite that infects the haemocyte of flat oysters. During infection, extracellular forms can also be found among the epithelial or interstitial cells in the gill, lobe, heart tissue, stomach or connective tissue of the oysters (Culloty \&Mulcahy 2007). These parasites are unicellular organisms with a diameter of 1 to $3 \mu \mathrm{m}$, also known as 'microcells' (Carnegie \& CochennecLaureau 2004). Bonamia ostreae, together with $B$. exitiosa, B. roughleyi and B. perspora, belong to the order Haplosporidia, within the phylum Cercozoa (Brehélin et al. 1982, Carnegie et al. 2000). Among these species, $B$. ostreae and $B$. exitiosa are the cause of serious internationally notifiable diseases (World Organisation for Animal Health [OIE] 2012).

Since its first identification in California (Elston et al. 1986), Bonamia ostreae has spread to Maine and Washington in North America and to France and Spain in Europe (Elston et al. 1986, Zabaleta \& Barber 1996, Cigarría \& Elston 1997). Furthermore, $B$. ostreae has also been found in many countries such as England, Italy, Ireland and the Netherlands, where production of flat oysters occurs (Bannister \& Key 1982, Figueras 1991, McArdle et al. 1991, Engelsma et al. 2010, Narcisi et al. 2010). As oysters are reared in the open area of the sea, it is impossible 
to develop effective methods to treat bonamiosis. Thus, preventing the transmission of the pathogen from infected areas to non-infected areas seems to be one of the most effective control strategies.

Several flat oyster species are known to be susceptible to Bonamia ostreae, for example, Ostrea edulis, $O$. angasi, $O$. puelchana and Crassostrea ariakensis (Carnegie \& Cochennec 2004, Audemard et al. 2005, OIE 2012). C. gigas may be a carrier or reservoir of B. ostreae and B. exitiosa (Lynch et al. 2010). Translocation of the above infected live hosts is recognized as a major underlying cause of the spread of bonamiosis. Considering the importance of the commercial exchange of live oyster stocks around the world and the associated risk of spreading the disease from infected to non-infected areas, many detection techniques have been developed. These techniques include microscopic observation, conventional PCR combined with restriction fragment length polymorphism (RFLP) analysis, real-time quantitative PCR (qPCR), in situ hybridization or fluorescent in situ hybridization (FISH) and electrochemical genosensors (Berthe et al. 1999, Carnegie et al. 2000, 2003, Cochennec et al. 2000, da Silva \& Villalba 2004, Corbeil et al. 2006, Narcisi et al. 2011). Among these methods, FISH is a powerful complement to morphological and PCR-based detection methods. PCR (using the genus-specific primers Bo-Boas), and RFLP analysis is the method recommended by the World Organisation for Animal Health (OIE) for identification of $B$. ostreae.

The biological characteristics of Bonamia sp., such as transmission, life cycle and in vitro survival ability, are still not fully understood. In this study, we examined 104 Ostrea edulis samples imported to China directly for consumption for the presence of $B$. ostreae. The infected material was used for further characterization of the pathogen. Considering the potential serious consequences of introducing the pathogen to China, the in vitro survival time of $B$. ostreae was studied to assess the introduction risk.

\section{MATERIALS AND METHODS}

\section{Sample collection and DNA extraction}

A total of 104 samples of Ostrea edulis, imported from the USA to China for consumption, were collected by the Guangdong Entry-Exit Inspection and Quarantine Bureau, PR China, in December 2011 and July 2012. DNA extraction was performed as described by Cochennec et al. (2000). After oyster shucking, gill tissue (50 mg) was collected and DNA was extracted using a QiaAmp DNA Mini-kit (Qiagen), according to the manufacturer's instructions. DNA was eluted into $50 \mu \mathrm{l}$ of sterile, deionized water and stored at $-20^{\circ} \mathrm{C}$ prior to PCR.

\section{PCR-RFLP identification}

PCR was used as the primary Bonamia ostreae screening method, as recommended by the OIE (2012). The reaction was expected to amplify a DNA fragment of approximately $300 \mathrm{bp}$. The PCR primers were as follows: Bo: 5'-CAT TTA ATT GGT CGG GCC GC-3', Boas: 5'-GGG GGA TCG AAG ACG ATC AG-3'. The $25 \mu \mathrm{l}$ PCR mixtures contained $2.5 \mu \mathrm{l}$ 10× Taq buffer, $2.5 \mathrm{mM} \mathrm{MgCl}_{2}, 0.2 \mathrm{mM}$ dNTP mix, $0.2 \mu \mathrm{M}$ Bo/Boas primers, $2.5 \mathrm{U}$ rTaq polymerase (TaKaRa) and $2 \mu \mathrm{l}$ DNA templates. The PCR reaction mixtures were denatured at $94^{\circ} \mathrm{C}$ in a thermocycler for $5 \mathrm{~min}$ before being submitted to 30 cycles of $94^{\circ} \mathrm{C}$ for $1 \mathrm{~min}, 55^{\circ} \mathrm{C}$ for $1 \mathrm{~min}$ and $72^{\circ} \mathrm{C}$ for $1 \mathrm{~min}$, followed by a final extension at $72^{\circ} \mathrm{C}$ for $10 \mathrm{~min}$. Subsequently, RFLP was performed. HaeII and BglI were used to digest the Bo-Boas amplicons. Then, $5 \mu$ l digested products were analyzed by electrophoresis on agarose gels, stained with SYBR-Green (Invitrogen) and visualized under UV light.

\section{Light microscopic observation}

A small piece of fresh gill tissue from the PCRpositive sample was sliced and fixed in Davidson's solution for $48 \mathrm{~h}$. Gill tissue from a PCR-negative sample was processed in the same way and used as a negative control. After dehydration, the tissues were embedded in paraffin. The paraffin blocks were then cut into $5 \mu \mathrm{m}$ thick sections. Paraffin sections from the same tissue block were stained with haematoxylin and eosin (H\&E) (Kim et al. 2006) or diamidino-2-phenylindole (DAPI), a fluorescent stain binding strongly to AT-rich regions in DNA. Subsequently, these sections were observed under an Olympus DP72 fluorescence microscope.

\section{In vitro survival time and purification}

To assess the potential risk of introducing Bonamia ostreae through importing oysters, the in vitro survival time of the parasite in the infected Ostrea edulis tissue was investigated. Whole body tissue of 
O. edulis was rinsed 3 times in sterile seawater and then decontaminated twice for $30 \mathrm{~min}$ in $30 \mathrm{ml}$ sterile seawater with an antimicrobial suspension (61.3 mg $\mathrm{l}^{-1}$ penicillin $\mathrm{G}, 131 \mathrm{mg} \mathrm{l}^{-1}$ streptomycin sulphate, $50000 \mathrm{U} \mathrm{l}^{-1}$ nystatin). The tissue was rinsed again and $4 \mathrm{ml}$ sterile seawater was added per $10 \mathrm{~g}$ of tissue. The tissue was cut into small pieces and homogenized for $10 \mathrm{~s}$ at $10 \mathrm{~s}$ intervals in a $50 \mathrm{ml}$ amicrobic tube using a GINGKO G20 Motor Driven Tissue Grinder until no obvious tissue pieces could be seen. The homogenate was then stored at $4^{\circ} \mathrm{C}$. Morphological observation of the cultivated parasites was performed under a light microscope. DNA extraction and PCR (using the Bo-Boas primers described above) was performed on a $0.5 \mathrm{ml}$ cultivation mixture once a week. After confirmation of infection status by PCR, 10 B. ostreae-free Crassostrea ariakensis collected from the Guangdong province were homogenized using the method described above and used as a control.

After cultivation at $4^{\circ} \mathrm{C}$ for $4 \mathrm{wk}$, the parasites were purified on sucrose gradients and then a Percoll gradient, following the method described by Mialhe et al. (1988). The 50 to $60 \%$ and 60 to $70 \%$ interface layers were collected and re-suspended in $100 \mu \mathrm{l}$ of seawater prior to FISH.

\section{Fluorescent in situ hybridization and viability}

The probe Bo-1 (5'-TCT GGC CCG GCG ATA CTA GCA CCC-3'-FITC), corresponding to a fragment inside the Bo-Boas amplicon and labelled with fluorescein isothiocyanate (FITC), was designed based on the consensus rDNA sequences of Bonamia ostreae. BLAST analysis of the probe revealed no cross matches; thus, it should be specific for B. ostreae. FISH was performed as described previously (Carnegie et al. 2003, Arzul et al. 2012) with some modifications. Purified parasites were fixed on silane-prep slides (Sigma), and the slides were then treated with pronase $\left(20 \mu \mathrm{g} \mathrm{ml}^{-1}\right.$ in double-distilled water [ $\left.\left.\mathrm{ddH}_{2} \mathrm{O}\right]\right)$ at $37^{\circ} \mathrm{C}$ for $10 \mathrm{~min}$. After pre-hybridization and hybridization (with $10 \mathrm{ng} \mathrm{\mu l}^{-1}$ probe or FITC) at $42^{\circ} \mathrm{C}$ overnight, the samples were washed 3 times in phosphate-buffered saline (PBS) with $0.1 \%$ Triton X-100 at $42^{\circ} \mathrm{C}$. Percoll gradient-purified parasite hybridized with FITC (Sigma) was chosen as a non-specific negative control. A healthy Ostrea edulis gill tissue section hybridized with the Bo-1 probe was used as a tissue control. Photographs of the FISH analysis were taken with the same fluorescence exposure time, using an Olympus DP72 fluorescence microscope.
Cell viability was determined using acridine orange-ethidium bromide staining, as described by Mialhe et al. (1988). In this assay, live cells appear green while dead cells appear orange.

\section{RESULTS}

\section{Detection of Bonamia sp. in Ostrea edulis}

Among the 104 collected oysters, 1 was suspected to be Bonamia-positive as PCR analysis resulted in a 300 bp product (Fig. 1). Sequencing and BLAST analysis of the $300 \mathrm{bp}$ PCR product indicated that this fragment had $100 \%$ identity with the rDNA of $B$. ostreae from the USA (AF262995) and France (AF192759). Subsequent RFLP analysis was carried out on the $300 \mathrm{bp}$ amplicon, using the endonucleases HaeII and BglI. The results showed that the $300 \mathrm{bp}$ amplicon could be digested by both enzymes (Fig. 1). Bands of approximately 110 and $190 \mathrm{bp}$ were obtained by digestion with HaeII, and of approximately 120 and 180 bp by digestion with BglI.

\section{Histological observation}

Histological examination by H\&E staining showed high numbers of Bonamia-like organisms in the gill tissues of the infected oyster. In the non-infected con-

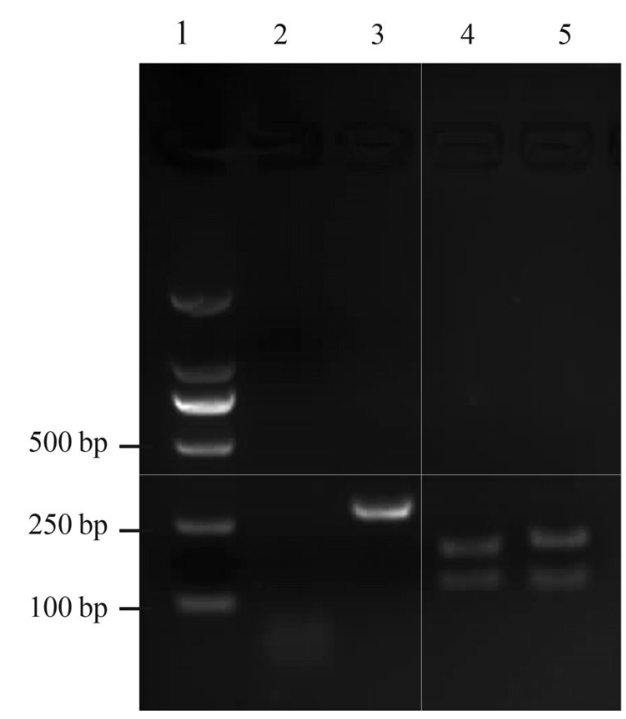

Fig. 1. Bonamia ostreae in Ostrea edulis. Agarose gel electrophoresis of Bo-Boas PCR amplicons. Lane 1: marker; Lane 2: negative control; Lane 3: PCR products (by Bo-Boas) from the positive infected sample; Lane 4: enzyme digestion of the amplicon by BglI; lane 5: enzyme digestion of the amplicon by HaeII 
trol, the host cells were usually basophilic (Fig. 2A). In the infected gill tissue, the Ostrea edulis cells and the uninucleated organisms were stained different colours by H\&E. The host cells were still basophilic, as in the non-infected control, while the uninucleated organisms inside the host haemocytes were eosinophilic (Fig. 2B). The uninucleated organisms were clustered in the host haemocyte or present as extracellular free particles, which were spherical or ovoid and approximately $2 \mu \mathrm{m}$ in diameter. As shown in Fig. 2C,D, the uninucleated organisms were stained blue by DAPI, indicating that they contain DNA and are microcells rather than epithelial eosinophilic granulocytes.

\section{In vitro survival time of Bonamia ostreae}

As an important biological characteristic, the in vitro survival time of Bonamia ostreae inside host homogenate was further investigated. PCR examination of the cultured mixture was carried out once a

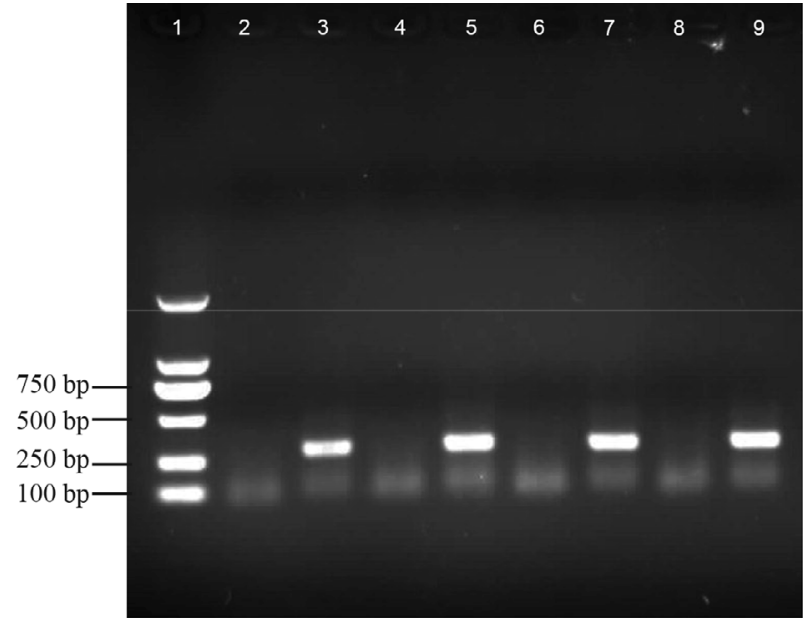

Fig. 3. Bonamia ostreae in Ostrea edulis. Weekly PCR detection of $B$. ostreae from the culture mixture. Lane 1: marker; Lane 2: PCR amplification from the negative control after $1 \mathrm{wk}$; Lane 3: PCR amplification from the B. ostreae culture mixture after $1 \mathrm{wk}$; Lane 4: the negative control after $2 \mathrm{wk}$; Lane 5 : the $B$. ostreae culture mixture after $2 \mathrm{wk}_{\text {; }}$ Lane 6 : the negative control after $3 w_{k}$; Lane 7 : the $B$. ostreae culture mixture after $3 \mathrm{wk}$; Lane 8: the negative control after $4 \mathrm{wk}$; Lane 9: the $B$. ostreae culture mixture after $4 \mathrm{wk}$
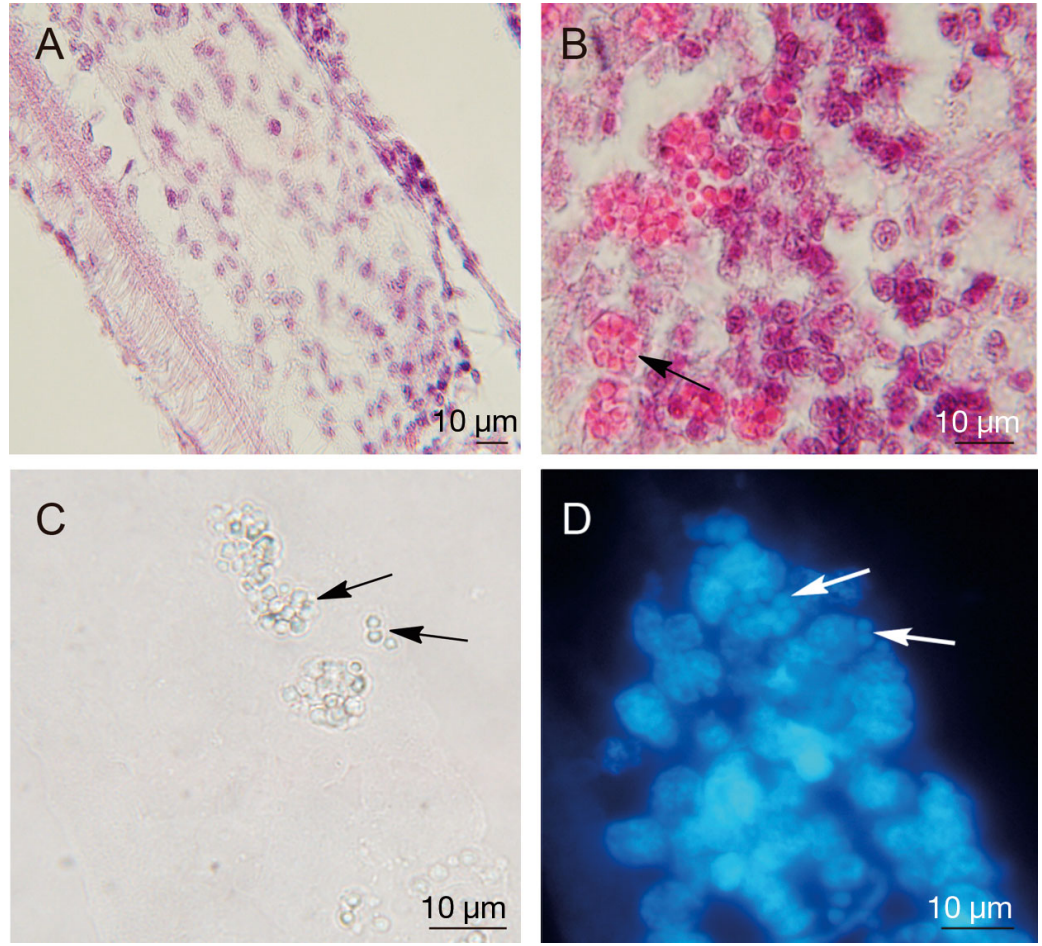

Fig. 2. Bonamia ostreae in Ostrea edulis. Histological observation of uninucleated organisms in gills. Haematoxylin and eosin (H\&E) staining of gill tissue from (A) healthy and (B) infected O. edulis. Arrow indicates a cluster of uninucleated organisms. (C,D) Another section from the same tissue block stained with DAPI; (C) shown under bright field and (D) the same view with DAPI-stained DNA fluorescing blue under UV light excitation. Arrows indicate uninucleated organisms, as in (B). Blue staining in (D) proves these cells contain DNA and are not host cell organelles week. Results showed that the $300 \mathrm{bp}$ product could be amplified from the culture after storage at $4^{\circ} \mathrm{C}$ for $4 \mathrm{wk}$. In contrast, no PCR product was amplified from the non-infected control (Fig. 3).

However, the PCR results could only demonstrate the presence of the DNA, not the living organism. The FISH assay is a powerful tool for the detection Bonamia ostreae (Carnegie et al. 2003) that can identify the pathogen both molecularly and histologically with little non-specific stain. Fig. 4A illustrates the autofluorescent background in the absence of probe in our FISH experiment. Only dark green autofluorescence and the black background could be observed. Fig. 4B indicates that no cross reaction between the probe Bo-1 and host tissue occurred. Fig. 4C shows that B. ostreae could be detected by the specific probe Bo-1 and were stained green. Most of the B. ostreae were clustered together, while some of them were free. The cells were approximately 1 to $2 \mu \mathrm{m}$, which is within the typical size range of $B$. ostreae. The morphol- 


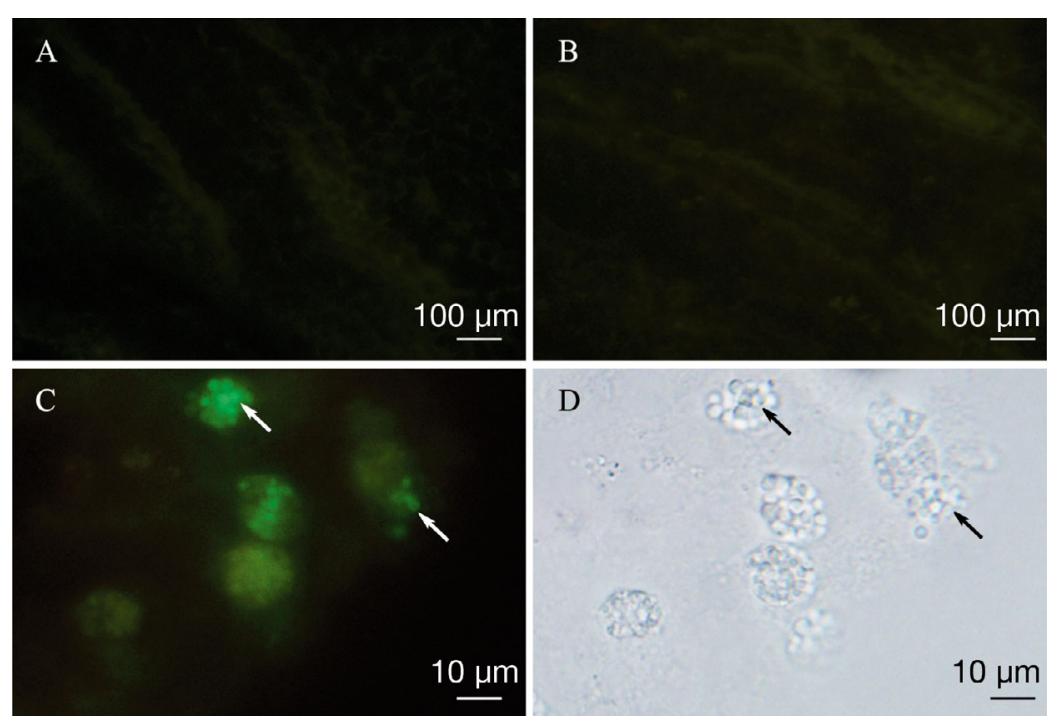

Fig. 4. Bonamia ostreae in Ostrea edulis. Fluorescent in situ hybridization (FISH) trials. (A) Control using FITC hybridized with purified parasites. The specific probe Bo-1 hybridized with (B) a healthy $O$. edulis gill tissue section or (C) with purified parasites. Arrows in (C) indicate clustered or single B. ostreae cells. (D) The same B. ostreae cells under light field. Arrows indicate the cell clusters

ogy of corresponding cells observed under light field was similar to that of the $B$. ostreae cells previously stained with H\&E (Fig. 4D).

To verify the viability of Bonamia ostreae, the cells were directly observed in light field and under fluorescence after staining with acridine orange and ethidium bromide. In light field, some cells showed the typical morphological characteristics of B. ostreae, including the round shape, 'fried egg' appearance, 1 to $2 \mu \mathrm{m}$ diameter and clustering together (Fig. 5A). These cells showed obvious integrity. Under fluorescence, some of these cells appeared green, which indicated that they were alive (Fig. 5B).
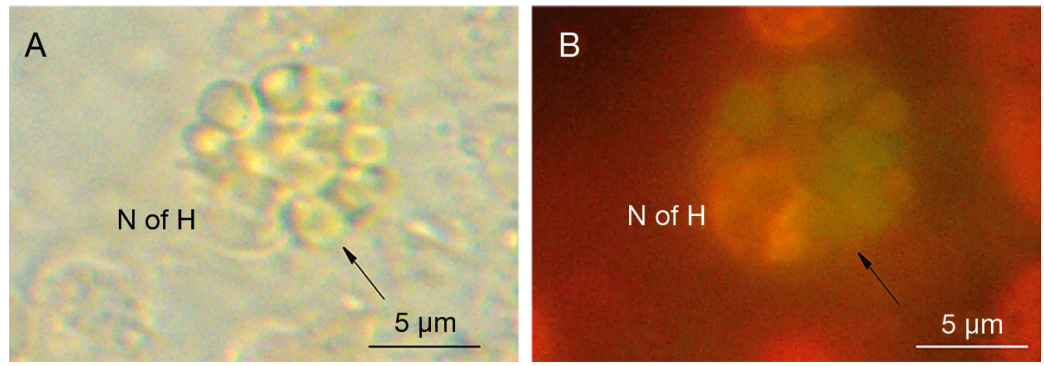

Fig. 5. Bonamia ostreae in Ostrea edulis. Detection of cell viability by acridine orange and ethidium bromide staining. (A) Cultured cells under light field. $B$. ostreae (arrow) are clustered near the nucleus of a host haemocyte ( $\mathrm{N}$ of $\mathrm{H}$ ). (B) Cultured cells under fluorescent field. B. ostreae cells are green and indicated by an arrow

\section{DISCUSSION}

Bonamia ostreae is an economically significant parasite of oysters and was originally enzootic in Europe and North America (Culloty \& Mulcahy 2007). Bonamiosis is not only notifiable to the OIE, but is also listed as a 'Class $\mathrm{C}$ ' disease and notifiable to the Ministry of Agriculture of China. Prior to this study, no official report of this disease had been recorded in Asian countries, including China, according to the OIE (www.oie.int/wahi2s_2/ public/wahid.php/Diseaseinformation/ WI\#) and the official veterinary bulletin of the Ministry of Agriculture of China (www.moa.gov.cn/zwllm/tzgg/ gb/sygb/). PCR-RFLP analysis of Crassostrea gigas (a potential carrier) and $C$. ariakensis (a susceptible host) from the Chinese coast, including the Bohai Sea, Yellow Sea and East China Sea, found them to be negative for Bonamia sp. infection (our previous epidemiological investigation in 2011, unpubl. data). It is very important to prevent the spread of this pathogen to China by developing reliable quarantine methods and paying special attention to transmission routes and the potential role of reservoir hosts. In this study, the in vitro survival time of $B$. ostreae was investigated to further assess the risk of introduction from imported oysters.

Our PCR and subsequent sequence analysis results confirmed that Bonamia ostreae DNA was present in 1 of the 104 imported oysters (Fig. 1). Furthermore, judging by morphological characteristics, B. ostreae-like uninucleated organisms were present in infected tissue (Fig. 2). Given that the oyster samples were imported for consumption and never removed from their travel packaging until arrival in our laboratory, it is almost certain that this oyster was infected before shipment.

Our investigation showed that Bonamia ostreae can survive in vitro at $4^{\circ} \mathrm{C}$, and retain typical cell morphology (Figs. 3, 4 \& 5). Temperature has been found to be one of the most important factors affecting the survival time of $B$. ostreae in vitro. Culloty \& Mulcahy (2007) demonstrated 
that lower temperatures are associated with increased bonamiosis prevalence. Arzul et al. (2009) proved that $B$. ostreae showed a significantly higher survival rate at $4^{\circ} \mathrm{C}$ compared to that at 15 and $25^{\circ} \mathrm{C}$. The survival rate of the pathogen after $2 \mathrm{~d}$ at $4^{\circ} \mathrm{C}$ ranged from 52 to $74 \%$, while at the higher temperature of $25^{\circ} \mathrm{C}$, this was reduced to $22-53 \%$. It has also been reported that low temperature can affect the defensive capabilities of the phagocytic haemocytes of flat oysters (Gagnaire et al. 2006), enabling the parasite to survive longer. Imported oysters are always maintained at a low temperature or on ice to keep them fresh during transportation and sale, which offers suitable conditions for the survival of $B$. ostreae and further increases the risk of introduction.

Bonamia sp. can be spread by reuse of contaminated equipment or by fouling on boat hulls in infected areas (Cigarría \& Elston 1997). Both of these could explain the presence of this parasite near a port in the eastern USA and in Spain (Friedman\& Perkins 1994, Cigarría \& Elston 1997, Abollo et al. 2008). However, biological characteristics of the pathogen such as in vitro survival time, which is a very important characteristic related to transmission, have not been well studied. Interestingly, according to our results, $B$. ostreae can survive for as long as 4 wk in vitro. This is significantly longer than the previously reported survival time of $1 \mathrm{wk}$ in filtered seawater (Arzul et al. 2009), or 2 wk in another study (Grizel 1985). More importantly, Guangdong province acts as a major production area of Crassostrea ariakensis and C. gigas in China (Wang 2004), and these may be the susceptible hosts or carriers of B. ostreae (Lynch et al. 2010, OIE 2012). If $B$. ostreae spreads to the culture beds of these oysters during its survival time, this may result in high prevalence. However, parasite survival for 4 wk under laboratory conditions may not be relevant to their survival in the wild. More experiments to investigate the survival time of $B$. ostreae in the wild need to be carried out.

In conclusion, this study confirmed the presence of Bonamia ostreae in imported Ostrea edulis. Our results suggest that, under the suitable conditions, $B$. ostreae might be able to survive in dead oysters for $4 \mathrm{wk}$. In the absence of proper quarantine, unsuitable disposal of dead infected $O$. edulis may potentially result in the release of viable infective pathogen into the sea and cause infection and disease. It is hoped that these results will contribute to a better understanding of the basic biology of this parasite as well as of the host-parasite relationship.
Acknowledgements. The project was supported by the National Science and Technology Support Program (2012BAK11B04). We thank Dr. T. Rapson and Dr. C. Dong for polishing the manuscript.

\section{LITERATURE CITED}

> Abollo E, Ramilo A, Casas SM, Comesaña P, Cao A, Carballal MJ, Villalba A (2008) First detection of the protozoan parasite Bonamia exitiosa (Haplosporidia) infecting flat oyster Ostrea edulis grown in European waters. Aquaculture 274:201-207

Arzul I, Gagnaire B, Bond C, Chollet B and others (2009) Effects of temperature and salinity on the survival of Bonamia ostreae, a parasite infecting flat oysters Ostrea edulis. Dis Aquat Org 85:67-75

Arzul I, Chollet B, Michel J, Robert M and others (2012) One Perkinsus species may hide another: characterization of Perkinsus species present in clam production areas of France. Parasitology 139:1757-1771

Audemard C, Carnegie R, Stokes NA, Burreson E, Bishop M (2005) Salinity effects on the susceptibility to and persistence of Bonamia ostreae and Bonamia sp. in Crassostrea ariakensis. J Shellfish Res 24:639

Bannister C, Key D (1982) Bonamia, a new threat to the native oyster fishery. Fish Nat MAFF Direct Fish Res 71:7

Berthe FCJ, Burreson EM, Hine M (1999) Use of molecular tools for mollusc disease diagnosis. Bull Eur Assoc Fish Pathol 19:277-278

Brehélin M, Bonami JR, Cousserans F, Vivarès CP (1982) True plasmodial forms exist in Bonamia ostreae, a pathogen of the European flat oyster Ostrea edulis. CR Seances Acad Sci III 295:45-48 (in French with English Abstract)

Carnegie RB, Cochennec-Laureau N (2004) Microcell parasites of oysters: recent insights and future trends. Aquat Living Resour 17:519-528

Carnegie RB, Barber BJ, Culloty SC, Figueras AJ, Distel DL (2000) Development of a PCR assay for detection of the oyster pathogen Bonamia ostreae and support for its inclusion in the Haplosporidia. Dis Aquat Org 42:199-206

> Carnegie RB, Barber BJ, Distel DL (2003) Detection of the oyster parasite Bonamia ostreae by fluorescent in situ hybridization. Dis Aquat Org 55:247-252

Cigarría J, Elston R (1997) Independent introduction of Bonamia ostreae, a parasite of Ostrea edulis, to Spain. Dis Aquat Org 29:157-158

Cochennec N, Le Roux F, Berthe F, Gerard A (2000) Detection of Bonamia ostreae based on small subunit ribosomal probe. J Invertebr Pathol 76:26-32

Corbeil S, Arzul I, Diggles B, Heasman M, Chollet B, Berthe FCJ, Crane MStJ (2006) Development of a TaqMan PCR assay for the detection of Bonamia species. Dis Aquat Org 71:75-80

Culloty SC, Mulcahy MF (2007) Bonamia ostreae in the native oyster Ostreae edulis. A review. Mar Environ Health Ser 29:1-36

da Silva PM, Villalba A (2004) Comparison of light microscopic techniques for the diagnosis of the infection of the European flat oyster Ostrea edulis by the protozoan Bonamia ostreae. J Invertebr Pathol 85:97-104

$>$ Elston RA, Farley CA, Kent ML (1986) Occurrence and significance of bonamiasis in European flat oysters Ostrea edulis in North America. Dis Aquat Org 2:49-54 
Engelsma MY, Kerkhoff S, Roozenburg I, Haenen OLM and others (2010) Epidemiology of Bonamia ostreae infecting European flat oysters Ostrea edulis from Lake Grevelingen, The Netherlands. Mar Ecol Prog Ser 409:131-142

Figueras AJ (1991) Bonamia status and its effects in cultured flat oysters in the Ria de Vigo, Galicia (N.W. Spain). Aquaculture 93:225-233

Friedman CS, Perkins FO (1994) Range extension of Bonamia ostreae to Maine. J Invertebr Pathol 64:179-181

Gagnaire B, Frouin H, Moreau K, Thomas Guyon H, Renault $\mathrm{T}$ (2006) Effects of temperature and salinity on haemocyte activities of the Pacific oyster, Crassostrea gigas (Thunberg). Fish Shellfish Immunol 20:536-547

Grizel H (1985) Etudes des récentes épizooties de l'huître plate Ostrea edulis L. et de leur impact sur l'ostreiculture Bretonne. PhD thesis, Université des Sciences Techniques du Languedoc, Montpellier

Kim Y, Ashton-Alcox KA, Powell EN (2006) Histological techniques for marine bivalve molluscs: update. NOAA Tech Memo NOS NCCOS 27

Lynch SA, Abollo E, Ramilo A, Cao A, Culloty SC, Villalba A (2010) Observations raise the question if the Pacific oyster, Crassostrea gigas, can act as either a carrier or a reservoir for Bonamia ostreae or Bonamia exitiosa. Parasitology 137:1515-1526

Editorial responsibility: Mike Hine, Fouras, France
McArdle JF, McKiernan F, Foley H, Jones DH (1991) The current status of Bonamia disease in Ireland. Aquaculture 93:273-278

> Mialhe E, Bachere E, Chagot D, Geizel H (1988) Isolation and purification of the protozoan Bonamia ostreae (Pichot et al. 1980), a parasite affecting the flat oyster Ostrea edulis L. Aquaculture 71:293-299

Narcisi V, Arzul I, Cargini D, Mosca F and others (2010) Detection of Bonamia ostreae and B. exitiosa (Haplosporidia) in Ostrea edulis from the Adriatic Sea (Italy). Dis Aquat Org 89:79-85

- Narcisi V, Mascini M, Perez G, Del Carlo M, Tiscar PG, Yamanaka H, Compagnone D (2011) Electrochemical genosensors for the detection of Bonamia parasite. Selection of single strand-DNA (ssDNA) probes by simulation of the secondary structure folding. Talanta 85:1927-1932

OIE (World Organization for Animal Health) (2012) OIE manual of diagnostic tests for aquatic animals. OIE, Paris

Wang H (2004) Studies on the molecular phylogeny and taxonomy of common oysters in China Sea. PhD thesis, Chinese Academy of Sciences, Beijing

Zabaleta AI, Barber BJ (1996) Prevalence, intensity, and detection of Bonamia ostreae in Ostrea edulis L. in the Damariscotta River area, Maine. J Shellfish Res 15: 395-400

Submitted: October 1, 2012; Accepted: June 17, 2013 Proofs received from author(s): August 21, 2013 